\title{
TRANSFORMASI BIROKRASI MELALUI E-GOVERNMENT
}

\author{
Umi Arifah \\ Lecturer at the IAINU Kebumen, Central Java, Indonesia and Doctoral \\ Candidates at the Universitas Diponegoro Semarang, Central Java, Indonesia \\ umiarifah87@gmail.com \\ ORCID iD: 0000-0003-2930-4115
}

\begin{abstract}
ABSTRAK
Kajian ini menyajikan tentang pelaksanaan transformasi birokrasi melalui $e$ government dan faktor yang mempengaruhi proses transformasi birokrasi. Metodologi yang digunakan dalam kajian ini menggunakan pendekatan kepustakaan (library research), dan pengumpulan data dilakukan dengan menelaah dan mengeksplor jurnal, buku, dan dokumen pendukung lainnya yang relevan dengan kajian yang dilakukan. Temuan dari kajian ini yaitu $e$ government harus dilaksanakan dengan serius dan konsisten akan sangat mendukung transparansi pelayanan publik. Transformasi birokrasi melalui $e$ government harus dilakukan dengan dukungan dari beberapa faktor yaitu a) dukungan regulasi, b) struktur organisasi, c) budaya organisasi, d) pembaharuan sistem. Selain itu jika e-government yang dilaksanakan secara serius dan konsisten akan sangat menunjang transparansi pelayanan publik. Yang juga harus dipahami oleh para birokrat bahwa pemanfaatan e-government tetap memerlukan sistem pengawasan yang konsisten. Selain pengetahuan yang luas tentang teknologi informasi, e-government juga harus didukung oleh integritas yang baik di antara para perumus kebijakan dan pelaksannya. Karena teknologi informasi memang membuat banyak hal semakin mudah dan semakin efisien.
\end{abstract}

Kata Kunci: Transformasi Birokrasi, E-Government, Pelayanan Publik

\section{Pendahuluan}

Pengembangan e-government pemerintah telah mengeluarkan Inpres Nomor 03 Tahun 2003 tentang Strategi Pengembangan e-government. Rumusan pengembangan e-government masih banyak perbedaan pemahaman di antara para pejabat pemerintah sendiri. Menurut masyarakat umum e-government masih dipahami sebatas sebagai pembuatan situs web oleh organisasi pemerintah. Belum banyak yang memahami secara luas bahwa tahap-tahap perkembangan 
pemanfaatan teknologi informasi dalam organisasi publik itu bisa berbedabeda mengikuti tuntutan kebutuhan masyarakat yang semakin beragam. Tetapi kurang jelasnya konsep e-government itu dapat dimaklumi karena cakupan tugastugas pemerintah yang sangat luas dengan kebutuhan di masing-masing daerah yang beragam.

Birokrasi memiliki kelemahan dalam pelaksanaannya dilapangan, ia memiliki citra buruk yang melekat dalam dirinya (the bad sides of bureaucracy) terutama dalam praktik pelayanan publik sehari-hari, khususnya di negara sedang berkembang yang mewarisi tradisi birokrasi yang korup dan kurang berpihak pada rakyat yang mestinya mereka layani. Birokrasi juga dianggap kaku dan formalistis, sebab tidak semua urusan masyarakat dan pemerintahan bisa didekati dengan pendekatan formalistis. Dalam sebuah masyarakat dan ekonomi yang semakin digerakkan oleh inovasi teknologi, birokrasi di negara-negara sedang berkembang harus berhadapan dengan proses tuntutan yang baru yaitu: efesiensi, produktifitas, akses rakyat terhadap informasi yang ada dalam birokrasi serta tuntutan kepastian dan rasa aman dan rasa nyaman.

\section{Metode Kajian}

Kajian ini dilakukan dengan menggunakan metode atau pendekatan kepustakaan (library research). Studi Kepustakaan merupakan serangkaian kegiatan yang berkaitan dengan metode pengumpulan data pustaka, membaca dan mencatat serta mengolah bahan penelitian (Zed, 2003:3). Penelitian studi kepustakaan memuat empat ciri utama yang perlu diperhatikan yaitu : a) Penulis berhadapan langsung dengan teks atau data angka, bukan dari pengetahuan langsung di lapangan; b) Data pustaka bersifat siap pakai, yaitu peneliti tidak secara langsung terjun kelapangan, namun peneliti berhadapan langsung dengan sumber data yang di perpustakaan; c) Data pustaka merupakan sumber sekunder, yang berarti bahwa peneliti memperoleh bahan atau data bukan dari data di lapangan; d) Kondisi data pustaka tidak dibatasi oleh ruang dan waktu (Zed, 2003:4-5). Teknik pengumpulan data dalam kajian ini dilakukan dengan 
Jurnal Cakrawala: Studi Manajemen Pendidikan Islam dan Studi

Sosial P-ISSN: 2580-9385, E-ISSN: 2581-0197

http:/ / ejournal.iainu-kebumen.ac.id/index.php/ cka/ index

melakukan telaah dan mengeksporasi jurnal, buku dan dokumen pendukung lainnya yang relevan dengan kajian yang dilakukan.

\section{Pembahasan}

\subsection{Konsep Dasar E-Government}

Bank Dunia (2001) mendefinisikan e-government sebagai penggunaan teknologi informasi oleh instansi pemerintah seperti Wide Area Networks (WAN), Internet, mobile computing) yang dapat digunakan untuk membangun hubungan dengan masyarakat, dunia usaha, dan instansi pemerintah lainnya. Sedangkan menurut Kurniawan dalam Hardiyansyah (2011), "e-government" diartikan sebagai kumpulan konsep untuk semua tindakan dalam sektor publik (baik di tingkat Pemerintah Pusat maupun Pemerintah Daerah) yang melibatkan teknologi informasi dan komunikasi dalam rangka mengoptimalisasi proses pelayanan publik yang efisien, transparan dan efektif. Sejalan hal tersebut, Purbo menyatakan bahwa e-government bukan sekedar memasang komputer di kantor masing-masing, karena e-government mempunyai banyak konsekuensi sosial budaya bagi pemerintah (terutama pemerintah daerah), karena e-government sebetulnya memaksa mereka bekerja secara profesional, bekerja bersih, tidak melakukan korupsi, tidak pungli dan lain-lain, karena komputer tidak bisa dibohongi dan tidak bisa mentolerir penipuanpenipuan, untuk itu aparat pemda harus merubah paradigamanya sebelum $e$ government ini bisa dijalankan dengan baik (Hardiyansyah, 2011).

Sedangkan definisi lain mengatakan bahwa e-government adalah penggunaan teknologi informasi untuk membuka pemerintah dan informasi pemerintah untuk memungkinkan dinas-dinas pemerintah untuk berbagi informasi demi kemanfaatan publik, untuk memungkinkan terjadinya transaksi secara online dan untuk mendorong pelaksanaan demokrasi. Melalui $e$ government paradigma pelayanan publik bergeser dari paradigma birokratis menjadi paradigma e-government yang mengedepankan efesiensi, transparansi, dan fleksibilitas, yang akhirnya bermuara pada kepuasan pengguna layanan publik. 
E-government Indonesia yang masih dalam tingkatan interaksi belum dapat mentransformasi pelayanan publik yang lebih baik. Bahkan untuk komunikasi eksternal pun masih belum dapat dimanfaatkan dengan baik walaupun sarana interaksi yang ada berupa forum, email, chat, polling, dan lainnya sudah disediakan pada setiap website pemerintah. Tantangan penerapan e-government di Indonesia masih sangat banyak di antaranya dari segi sumber daya manusia, perangkat keras, dan organisasi. Operasionalisasi e-government kurang berjalan lancar karena sarana interaksi yang disediakan tidak dimanfaatkan dengan baik. Hal tersebut membuktikan bahwa paradigma pelayanan publik berbasis $e$ goverment memerlukan persiapan yang lebih serius, bukan hanya implementasi aplikasi saja.

Aspek teknologi dan infrastuktur juga menjadi tantangan karena terbatasnya hardware dan software serta masih sedikitnya instansi pemerintah yang terhubung pada jaringan baik lokal maupun global. Seharusnya melalui implementasi e-government komunikasi internal antar dinas pernerintah dapat lebih terjalin. Sedangkan dalam aspek organisasi, seringkali instansi pemerintah dalam mengoperasionalkan e-government menemui kendala. Kendala ini ditandai dengan tidak fleksibelnya Struktur Organisasi dan Tata Kerja (SOTK) birokrasi yang dapat mewadahi perkembangan baru model pelayanan publik melalui $e$ government.

\subsection{E-Government Sebagai Modernisasi Birokrasi}

Dalam buku "Breaking Through Bureaucracy: A New Vision for Managing in Goverment" (1992), Michael Barzeley menggunakan istilah "post-bureaucracy paradigm" untuk menggambarkan perubahan dari model birokrasi tradisional menuju sistem manajemen publik modern. Konsep manajemen publik baru menurut Barzeley memiliki karakteristik berikut:

1. Pergeseran dari kepentingan publik menjadi fokus pada hasil dan citizen's value.

2. Pergeseran dari efisiensi menjadi fokus pada kualitas dan value (efektivitas).

3. Pergeseran dari administrasi menjadi produksi pelayanan.

4. Pergeseran dari ketaatan pada aturan (norma) ke fokus pada pengendalian. 
5. Pergeseran dari penentuan fungsi, otoritas dan struktur menjadi fokus pada misi, pelayanan pelanggan dan outcomes.

6. Pergeseran dari pertimbangan biaya menjadi fokus pada pemberian nilai (value).

7. Pergeseran dari memaksakan tanggung jawab menjadi membangun tanggung jawab.

8. Pergeseran dari mengikuti aturan dan prosedur menjadi berfokus pada pemahaman dan penerapan norma, identifikasi dan penyelesaian masalah, serta perbaikan proses secara berkelanjutan.

9. Pergeseran dan pemenuhan sistem administratif menjadi fokus pada pelayanan dan pengendalian, memperluas pilihan publik, mendorong tindakan kolektif, pemberian insentif, pengukuran dan analisis hasil kinerja serta pemberian feedback.

Merujuk pada konsep Barzeley adanya perubahan dari model birokrasi tradisional menuju sistem manajemen publik modern, e-government merupakan upaya dalam modernisasi birokrasi. Melihat bahwa trend aplikasi e-government dalam pemerintahan serta hasil yang telah dicapai oleh beberapa negara maju mengesankan bahwa negara yang ingin memperbaiki pelayanan publiknya, maka harus berinovasi dalam manajemen pelayanan dan peningkatan mutu pelayanan publiknya. Perbaikan mutu dalam pelayanan publik harus dilakukan dengan inovasi dan salah satu inovasi yang dilakukan yaitu dengan e-government. Terdapat penilaian bahwa e-government adalah aplikasi teknologi informasi dan komunikasi diharapkan meningkatkan performance pemerintahan dan memenuhi ekspektasi masyarakat akan peningkatan kualitas pemerintahan.

\subsection{Tahapan Dalam Melakukan Transformasi Birokrasi}

Upaya dalam rangka untuk memperbaiki birokrasi, sistem birokrasi, pembenahan personel maupun budaya yang melingkupinya, dan aplikasi IT dalam birokrasi memang penting. Cepat atau lambat Indonesia akan mengejar efisiensi dan produktifitas pelayanan publiknya sesuai dengan demand masyarakat sekitarnya. Dengan kata lain fasilitas e-government di tingkat pusat dan propinsi di Indonesia memang perlu mendapat dukungan.

Di Indonesia, pembenahan birokrasi biasanya dilakukan melalui pendekatan incremental, perubahan yang sedikit demi sedikit, dengan harapan antara lain agar 
didapatkan perubahan yang terencana (guidance development). Transformasi pemerintahan yang modern dengan menggunakan teknologi komunikasi dan informasi ke dalam kalangan birokrasi, bukanlah hal yang mudah. Konsep transformasi dalam konteks ini perancangan ulang terhadap aspek-aspek genetika birokrasi yang menjadi penggerak utama suatu organisasi. Di dalamnya tercakup 4 domain yang dikenal sebagai $4 \mathrm{R}$, yaitu Renew, Reframe, Restructure, dan Revitalize (Gouillart dan Nelly, 1995). Keempat komponen transformasi tersebut harus dilakukan bersamaan, sebagai syarat utama bagi suatu organisasi untuk sukses dan berkelanjutan. Secara ringkas, fungsi dari ke empat komponen tersebut dijelaskan dibawah ini.:

\section{a. Reframing}

Organisasi yang sudah mapan cenderung terjebak pada pola pikir tertentu yang sudah terbentuk selama bertahun-tahun, sehingga cenderung tidak mampu mengembangkan mental model yang baru. Proses Reframing akan membuka pola pikir agar mampu mengembangkan visi dan pandangan baru yang lebih progresif tentang jati diri (eksistensi dan kompetensi) korporat atau birokrasi.

Reframing bukanlah hal yang mudah untuk dilakukan, karena adanya bentuk keengganan untuk berubah, penolakan terhadap terobosan, keberpihakan pada status quo, dan penolakan terhadap nilai-nilai baru. Mengatasi halanganhalangan tersebut merupakan kendala terbesar dalam proses transformasi, karena yang kita hadapi bukan sekedar halangan dalam bentuk fisik, tetapi sikap emosi manusia yang sukar untuk diubah.

Proses Reframing berusaha merobohkan dinding-dinding penghalang tersebut dan sekaligus menyiapkan mental untuk bergerak melewatinya. Proses tersebut akan mencakup perubahan pola pikir, motivasi, standar penilaian, dan bahkan juga nilai-nilai dan norma bisa ikut berubah. Keberhasilan Reframing tergantung pada tiga pilarnya, yaitu: (1) membangun visi bersama, a sense of purpose, yang bertahan untuk jangka waktu yang cukup lama; (2) mobilisasi skala korporat; dan (3) membangun tolok ukur kemajuan. 


\section{b. Restructuring}

Restrukturisasi adalah proses yang biasanya memberikan hasil lebih awal, tetapi juga yang paling menimbulkan stress. Keberhasilan melakukan restrukturisasi harus dibarengi dengan Renewal dan Revitalization agar sukses dapat terus dipertahankan dalam jangka waktu yang panjang. Proses Restructuring melatih dan menggerakkan seluruh komponen organisasi agar bergerak ke arah yang dinginkan. Sebaik apapun visi, misi, dan program organisasi, semuanya tidak akan menghasilkan apa-apa jika komponen yang ada dalam organisasi tidak melaksanakannya. Karena itu restrukturisasi harus dilakukan dalam tubuh organisasi, termasuk asset-aset dan sumberdaya yang dimilikinya, proses-proses internal, system alokasi sumberdaya, strategi operasional, alur kerja, serta sinergitas dari semua proses dan sumberdaya yang ada.

Restrukturisasi juga menelaah hubungan antara visi-misi organisasi dengan proses dan prioritas kegiatan yang menjadi salah satu kunci agar organisasi dapat terus bertahan. Untuk itu restrukturisaksi perlu diarahkan untuk: (1) pengembangan sumberdaya, resource generator, dan economic model (bagi entitas bisnis); (2) penguatan infrastruktur dan komponen fisik; dan (3) pengembangan arsitektur kerja yang lebih efisien; melakukan reorganisasi kerja dan proses sehingga mampu menghasilkan perbaikan secara dramatik dalam aspek-aspek kualitas, efisiensi, dan biaya.

\section{c. Revitalization}

Proses revitalisasi dilakukan dengan membangun hubungan-hubungan baru antara eksistensi dan kompetensi organisasi dengan lingkungan strategisnya. Peluang-peluang untuk pertumbuhan sering kali tidak tampak dengan jelas, sehingga diperlukan kejelian dalam melakukan revitalisasi. Proses Revitalisasi akan membawa kehidupan baru ke dalam organisasi, antara lain dengan mengembangkan lebih jauh proses yang sudah ada atau mengembangkan hal-hal baru untuk menjawab tuntutan stakeholders dan mengikuti perubahan dan perkembangan lingkungan strategis. Kecederungan jajaran birokrasi adalah bersikap defensif ketika terjadi kendala, antara lain dengan melakukan penghematan, pengurangan kegiatan, dan sejenisnya, bukan mencari peluang baru 
dan melakukan inovasi atau terobosan. Untuk itu revitalisasi harus diupayakan berorientsi pada: (1) pemangku kepentingan/customer oriented; (2) pengembangan dan inovasi (system manajemen dan produk); dan (3) pengembangan IT.

\section{d. Renewal}

Sumber daya manusia harus dibekali dengan keterampilan dan semangat yang baru, serta mengembangkan tujuan-tujuan dan target baru sehingga organisasi selalu mampu melakukan regenerasi dari waktu ke waktu untuk mengikuti perubahan dan perkembangan di lingkungan strategisnya. Proses renewal umumnya tidak begitu tampak ke permukaan, tetapi berperan paling vital dalam proses transformasi organisasi.

Renewal dimulai dengan adanya rewards, berupa kompensasi, penghargaan, persahabatan, keterikatan social, atau bentuk-bentuk lainnya yang menjadi pengikat antara individu (SDM) dengan organisasi induknya. Pada level tertentu, ketika emosi sudah cukup terbangun dengan baik maka orang-orang tidak lagi termotivasi oleh rewards. Hubungan antara individu dengan lembaga akan berubah, dimana individu tidak lagi memandang lembaga sebagai sumber pemberi penghasilan semata, tetapi sebagai bagian dari hidupnya. Sikap individu mulai bergeser mengambil tanggungjawab lembaga sebagai tanggungjawab pribadi. Termasuk dalam upaya pengembangan diri sehingga mampu menjadi pebelajar yang aktif. Indvidu dalam lembaga mengejar prestasi bukan lagi untuk mencari rewards semata, tetapi sebagai upaya untuk aktualisasi diri dan memberikan impact yang significant kepada lingkungannya. Tataran ini diekspresikan dalam pidato John F. Kennedy: "Ask not what your country can do for you, but ask what you can do for your country".

\subsection{Faktor Yang Mempengaruhi Proses Transformasi Birokrasi}

Pemanfaatan e-government seharusnya mampu meningkatkan partisipasi warga dalam memberikan informasi dan keluhan kepada pemerintah daerah/ kota. Namun ada persoalan terkait dengan kecepatan respon birokrasi dalam menjawab keluhan dan tuntutan warga. 
Dalam pelaksanaan e-goverment terdapat faktor-faktor yang mempengaruhi terhadap pelayanan publik, sebagai berikut:

\section{a. Dukungan Regulasi}

Pelaksanaan e-government harus didukung dengan regulasi yang kuat, sehingga akan memudahkan dalam implementasinya. Regulasi ini dilakukan secara berjenjang dari tingkat Pusat hingga Daerah. Namun terkadang regulasi saja tidak cukup namun penting adanya inovasi dan dan komitmen stakeholder yang berwenang sehingga akan mendukung dalam pelaksanaan e-government untuk pelayanan publik

\section{b. Struktur organisasi}

Struktur organisasi di pemerintahan daerah dalam pelaksanaan $e$ government membutuhkan hubungan antar aparat bersifat horizontal. Pelu adanya pendelegasian kewenangan top manager dalam konteks relasi dengan warga, dalam arti hal-hal yang bisa direspon secara cepat tidak perlu rapat, karena hal ini bisa diselesaikan dengan komunikasi elektronik misal dengan SMS, BBM, WA maupun dengan telepon. Seharusnya pimpinan middle manager tidak harus menunggu laporan admin, tetapi bisa akses langsung dimanapun, selanjutnya merespon sesuai perencanaan program tahunan

\section{c. Budaya organisasi}

Fakta di lapangan sebagian pimpinan birokrasi di daerah belum familiar dengan e-government, sehingga tidak menempatkan kebutuhan e-government pada posisi yang prioritas, seolah sistem ini hanya menjadi pelengkap di instansi. Faktor kepemimpinan dengan politisasi birokrasi sangat berpengaruh dalam pelaksanaan suatu kebijakan yang ditetapkan oleh pemerintah daerah. Manajemen pemerintah yang lebih fleksibel, aparat bergerak sesuai regulasi, dan selalu beradaptasi dengan berbagai perubahan kebutuhan para pelanggan, baik yang berasal dari kalangan birokrat sendiri (internal) maupun dari luar lembaga pemerintahan (eksternal). Kunci sukses manajemen dengan gaya fleksibel ini terletak pada kemampuan para birokrat bekerja secara tim (teamwork). 


\section{d. Pembaharuan sistem e-government}

Pembaharusn sistem harus dilaksanakan sebagai upaya untuk memperbaiki dan meningkatkan pelayanan terhadap masyarakat. Karena kebutuhan yang ada di masyarakat akan semakin berkembang dan adanya tuntutan efisiensi dan efektifitas kinerja. Sistem yang dikembangkan dengan kebaruan konten akan mengakomodir kebutuhan masyarakat terkait pelayanan publik.

Rendahnya transformasi birokrasi berbasis e-government, perlu dibangun birokrasi virtual yakni suatu sistem birokrasi baru yang didalamnya sudah mengalami perubahan mindset kearah e-government, birokrasi dengan perubahan kultur, serta produk kebijakan yang bisa menggerakkan dan mendukung aplikasi e-government dalam menjalankan pelayanan publik.

\section{Kesimpulan}

Kinerja e-government Indonesia masih harus ditingkatkan baik oleh pihak internal maupun eksternal pemerintah. Dengan disahkannya Undangundang tentang Informasi dan Transaksi Elektronik (UU ITE) maka diharapkan e-government akan dapat lebih dirasakan oleh masyarakat. Transformasi birokrasi melalui e-government harus dilakukan dengan dukungan dari beberapa faktor yaitu a) dukungan regulasi, b) struktur organisasi, c) budaya organisasi, d) pembaharuan sistem. Selain itu jika e-government yang dilaksanakan secara serius dan konsisten akan sangat menunjang transparansi pelayanan publik. Yang juga harus dipahami oleh para birokrat bahwa pemanfaatan $e$ government tetap memerlukan sistem pengawasan yang konsisten. Selain pengetahuan yang luas tentang teknologi informasi, e-government juga harus didukung oleh integritas yang baik di antara para perumus kebijakan dan pelaksannya. Karena teknologi informasi memang membuat banyak hal semakin mudah dan semakin efisien. 
\begin{tabular}{l|l} 
Jurnal Cakrawala: Studi Manajemen Pendidikan Islam dan Studi & Vol.4 No.2 Th 2020
\end{tabular}

Sosial P-ISSN: 2580-9385, E-ISSN: 2581-0197

http:/ / ejournal.iainu-kebumen.ac.id/index.php/ cka/ index

\section{DAFTAR PUSTAKA}

Arifah, U., Suwitri, S., Larasati, E. and Yuwanto. (2020). Contributing Factors : Implementation of Poor Population Data Collection. Management and Entrepreneurship: trends of development, Vol. 2, Issue 12, pp. 59-73

Cordella, Antonio., Niccolò Tempini. (2015). E-government and organizational change: Reappraising the role of ICT and bureaucracy in public service delivery. Journal of Government Information Quarterly 32. 279-286

Diaby, Aboubacar., Kevin Sylwester. (2014). Bureaucratic Competition and Public Corruption: Evidence from Transition Countries. European Journal of Political Economy 35 (2014) 75-87

Hardiyansyah. (2017). Manajemen Pelayanan dan Pengembangan Organisasi Publik: Dalam Perspektif Riset Ilmu Administrasi Publik Kontemporer. Yogyakarta: GAVA MEDIA

Kumar, Sushil; Shashi Kant. (2005). Bureaucracy and new management paradigms: modeling foresters' perceptions regarding. community-based forest management in India - Forest Policy and Economics 7. 651- 669

Mahmudi. (2015). Manajemen Kinerja Sektor Publik. Yogyakarta: UPP STIM YKPN

Mustapa, Z. (2011). Reformasi Birokrasi Melalui E-Governance: Peluang atau Tantangan Dalam Pelayanan Publik?. OTORITAS: Jurnal Ilmu Pemerintahan, 1(2), 146-155.

Nograšek, Janja; Mirko Vintar. (2014). E-government and organisational transformation of government: Black box revisited?. Government Information Quarterly 31. 108-118

Supardal. (2016). Penerapan ICT dalam Pelayanan Publik di Kabupaten Bantul. OTORITAS: Jurnal Ilmu Pemerintahan, 6 (2), 120-134.

Supriyadi. (2016). Community Of Practitioners: Solusi Alternatif Berbagi Pengetahuan antar Pustakawan. Jurnal Lentera Pustaka 2 (2):83-93.

Voet, Joris van der. (2014). The effectiveness and specificity of change management in a public organization: Transformational leadership and a 
\begin{tabular}{ll|l} 
Jurnal Cakrawala: Studi Manajemen Pendidikan Islam dan Studi & Vol.4 No.2 Th 2020
\end{tabular} Sosial P-ISSN: 2580-9385, E-ISSN: 2581-0197 http:/ / ejournal.iainu-kebumen.ac.id/index.php/cka/ index

bureaucratic organizational structure. European Management Journal 32. $373-382$

Wiatr,. Jerzy J. (1995). The Dilemmas of Re-organizing the Bureaucracy in Poland during the Democratic Transformation. Community und PostCommunist Studrrs Vol. 28, No. 1, pp.1 53-16109

Wiranta, Dayat NS. (2015). Transformasi Birokrasi: Cara untuk Penguatan Etika dan Integritas dalam Pencegahan Korupsi. Jurnal Lingkar Widyaiswara Edisi 2 No. 4, Okt - Des 2015, p.44-71

Zed, Mestika. (2003). Metode Penelitian Kepustakaan. Jakarta : Yayasan Obor Indonesia 